\title{
Methodological aspects of the institutional analysis of the level of regional infrastructure development
}

\author{
Oxana Komarova* \\ Ural State University of Economics, March 8/Narodnaya Volya Str., 62/45, 620144 Ekaterinburg, \\ Russia
}

\begin{abstract}
The development of the region's infrastructure is one of the goals of territorial sustainable development. Regional infrastructure improves the quality of life. The article provides a theoretical analysis of methods for assessing the level of infrastructure development. The development of infrastructure is determined by the interests of many stakeholders. This determines the need for taking into consideration the institutional conditions of its development. The goal of the study is to analyze methods for assessing the development of regional infrastructure and substantiate the need for an institutional analysis of infrastructure development. To achieve this goal, methods of analysis, generalization and synthesis of studies on measuring and assessing the level of development of regional infrastructure were used. To form a methodology for assessing regional infrastructure, we used the methods of institutional analysis, comparison and generalization of scientific research. To ensure an increase in the efficiency of regional infrastructure development, the methodology for assessing the institutional conditions for infrastructure development is proposed. The methodology is based on the following indicators: regulatory framework for infrastructure development, assessment of infrastructure development forms in projects for interaction between business and the state, infrastructure development tools, availability of a system for coordination and monitoring of infrastructure development, technological level of the region's infrastructure. Further research involves testing the methodology for assessing the level of development of regional infrastructure. In general, a systematic approach to the development of the region's infrastructure is fully consistent with the goals of sustainable development and allows us to identify markers of infrastructure development that correspond to the level of territorial development.
\end{abstract}

\section{Introduction}

The development of regional infrastructure is one of the most important mechanisms for ensuring sustainable development. In its most general form, infrastructure is considered to be a component of the socio-economic system of the region, contributing to the

\footnotetext{
*Corresponding author: okkomarova@yandex.ru
} 
development of economy. S. Schindler, J.M. Kanai consider infrastructure as "spatially articulated value chains aimed at resource extraction, logistics integration and industrial production" [1]. Infrastructure is not limited to material objects of regional socio-economic systems, but includes intangible networks - social, business and cultural [2; 3].

J.-P. D. Addie, M. R. Glass, J. Nelles argue that the concepts of "region" and "infrastructure" are interrelated: on the one hand, infrastructure is a factor for regional development; on the other hand, the main characteristics of a region determine the development of its infrastructure [4]. Regional infrastructure development is viewed by D.L. Bennett as a dynamic process, since infrastructure is the accumulation of past investments over a long period of time, which are aimed at changing the external environment of entrepreneurial activity [5]. A characteristic feature of infrastructure is its duality: on the one hand, the existence of the production sector is impossible without the development of infrastructure, on the other hand, the creation of infrastructure and its operation is not always profitable, but contributes to the growth of profits and the expansion of the production sector.

A special focus of research on regional infrastructure is justified by the ability of the developed infrastructure of a region to enhance positive externalities [6], as well as the need to provide the population of the territory with local public goods, harmonize interregional interests and reduce the differentiation of regional development. Wang H., Xiong W., Wu G., Zhu D. note that not only the system of formal institutions created by the central government is important, but also the development of institutions at the level of local government, professional and independent communities [7].

Thus, infrastructure can be considered as a system for ensuring interactions in the regional economic system, aimed at formation of sustainable development of a territory and a high standard of living of its population.

In modern studies, infrastructure development is associated with large private or public investments, characterized by significant sunk and irreversible costs [8]. In this case, the key issue in the development of regional infrastructure is the choice between optimality and efficiency of financial investments. Since the development of infrastructure is determined by the interests of many economic subjects of households, both enterprises and public administration, it becomes necessary to develop an institutional model for managing the infrastructure of the region. The key problem is multilateral understanding of the mechanisms of regional infrastructure for effective management in economic and public interests.

Therefore, the goal of the study is the analyses of methods for assessing regional infrastructure development and substantiation of the need for institutional analysis of infrastructure development.

\section{Materials and Methods}

To achieve this goal, several methods were used. To analyze theoretical and methodological aspects of the problem, we used a review of Russian and foreign scientific studies which results are presented in the Scopus and Web of Science databases for 20132020. For a multilateral understanding of methods for assessing regional infrastructure, generalization of various points of view on the methods of measuring regional infrastructure to ensure sustainable development of society was used. To form methodology for assessing regional infrastructure, we applied the methods of institutional analysis, comparison and generalization of scientific research. To provide a comprehensive presentation of benchmarking results, we used a tabular method. 


\section{Results and Discussion}

Currently, two indices are used to assess the level of regional infrastructure development: the urban environment quality index and the infrastructure development index. The urban environment quality index includes 36 indicators and is assessed taking into consideration the size of a city and climatic conditions [9]. The infrastructure development index takes into account the development of five types of public infrastructure in a region: transport, energy, social one, utilities and telecommunications - the maximum value of the index is 10 [10]. The analysis of both methods showed that these indices reflect the general level of infrastructure development, and despite the presence of certain parameters for assessing infrastructure development, some of the essential factors and indicators of its development remain unexplored.

The study by Y. Theodora notes that the development of modern infrastructure takes the form of redevelopment programs, which often has a corrective nature. Y. Theodora proposes to apply an integrated approach to infrastructure development based on the management of material, human and cultural resources; the goals and methodology of development are the key determinants; development tools; spatial scale; interaction between customers and participants and availability of funding [3].

D. Rehak et al. proposes a comprehensive assessment of the stability of critical infrastructure elements, which takes into account functional, structural and operational parameters of infrastructure. This increases the efficiency of the use of infrastructure facilities and their management [11].

An alternative approach to considering infrastructure is the ecosystem approach, on the basis of which effective infrastructure is assessed on the principles of integrity, complexity, representativeness, efficiency, versatility, sustainability and public funding [12]. The ecosystem approach makes it possible to form the most favorable infrastructure, but the proposed methodology does not take into cosideration the social factors which determine the development of infrastructure. This means that this approach to the assessment and development of infrastructure is incomplete.

J.-P.D. Addie, M. R. Glass, J. Nelles in their he study define dependence of infrastructure development not only according to location, type, decision-making process and source of investment in infrastructure, but also taking into account the socio-economic and political landscape of a region, the influence of institutions and global flows [4].

E.V. Ufimtseva et al. offer a comprehensive methodology for assessing development of infrastructure, which takes note not only quantitative, but also qualitative parameters. This methodology consists of more than 13 blocks of indicators, and does not provide an assessment of the conditions for infrastructure formation [13].

Thus, application of institutional analysis of infrastructure could provide not only a comprehensive assessment of the level of infrastructure development, but also increase the efficiency of its development. An important area of analysis of institutions is the analysis of their structure.

Komarova O.V. proposes to analyze institutions on the basis of assessment of their internal structure, which includes the following: legal and regulatory framework; development and support programs for the relevant area; state administrative apparatus and the system of infrastructural organizations that ensure interaction between the state and business (both market and public) [14].

Considering previous research in the field of institutional economics, it is proposed to analyze infrastructure on the basis of assessment of completeness of institutional structure in accordance with the indicators presented in Table 1: assessment of the presence or absence of regulatory framework for infrastructure development, assessment of infrastructure development forms in projects of interaction between business and state, 
development tools infrastructure, availability of the system for coordination and monitoring of infrastructure development, and technological level of the region's infrastructure.

Table 1. Methodology for institutional analysis of the level of regional infrastructure development

\begin{tabular}{|c|c|}
\hline Analysis parameters & Parameter content \\
\hline $\begin{array}{l}\text { Regulatory framework for } \\
\text { infrastructure development }\end{array}$ & $\begin{array}{c}\text { The presence / absence of regulatory framework for } \\
\text { infrastructure development; level of development of formal } \\
\text { institutions }\end{array}$ \\
\hline $\begin{array}{c}\text { Variety of infrastructure } \\
\text { development forms }\end{array}$ & Possibilities for formation of specific forms of partnerships \\
\hline $\begin{array}{l}\text { Systematic development of } \\
\text { infrastructure }\end{array}$ & $\begin{array}{l}\text { Consistent expedient development of infrastructure aimed at } \\
\text { improving the quality of life, satisfaction of population with } \\
\text { the level of infrastructure development }\end{array}$ \\
\hline $\begin{array}{c}\text { Infrastructure development } \\
\text { coordination and monitoring } \\
\text { system }\end{array}$ & $\begin{array}{l}\text { Availability / absence of the system for monitoring the } \\
\text { quantity and quality of infrastructure; availability of a single } \\
\text { coordinating body for infrastructure development }\end{array}$ \\
\hline Infrastructure development tools & Design / program method \\
\hline $\begin{array}{l}\text { Technological level of } \\
\text { infrastructure development }\end{array}$ & $\begin{array}{l}\text { Compliance of infrastructure facilities with modern } \\
\text { technologies }\end{array}$ \\
\hline
\end{tabular}

Using these parameters for assessing the level of infrastructure development will complement the existing methods, from the standpoint of analyzing the institutional conditions of a region. Each of the proposed parameters for assessing infrastructure is aimed at forming a holistic view of infrastructure development system and creating a systematic approach to infrastructure projects in regional management structures.

\section{Conclusion}

The results of the analysis of the methods for assessing the level of regional infrastructure development show that it is necessary to form a unified comprehensive methodology for assessing the development of the infrastructure level. This is justified by a significant role of infrastructure in ensuring sustainable development of a territory. Comprehensive methodology, in our opinion, is provided not only by the assessment of infrastructure qualitative and quantitative parameters and its comfort for the residents. Assessment of systematic development of infrastructure also should be provided. Thus, it is proposed to evaluate systematic nature of infrastructure development on the ground of applying institutional analysis.

Therefore, it is proposed to supplement the methods for assessing the level of regional infrastructure considering the following indicators: regulatory framework for infrastructure development, assessment of forms of infrastructure development in projects of interaction between business and state, infrastructure development tools, availability of the system for coordination and monitoring of infrastructure development, technological level of region's infrastructure. The presence of a coordination system is especially relevant, since it allows to avoid fragmentation and ensures coordination in infrastructure development [15].

Further research involves testing the methodology for assessing the level of regional infrastructure development. On the whole, systematic approach to the development of regional infrastructure is completely consistent with the goals of sustainable development and allows us to identify markers of infrastructure development which correspond to the level of territorial development. 


\section{References}

1. S. Schindler, J.M. Kanai, Regional Studies, 55, 40 (2021)

2. S. Mohebbi, Q. Zhang, E.C. Wells, T. Zhao, H. Nguyen, M. Li, N. Abdel-Mottaleb, Sh. Uddin, Q. Lu, M. J. Wakhungu, Z. Wu, Y. Zhang, A. Tuladhar, X. Ou, Sustainable Cities and Society, 62, 102327 (2020)

3. Y. Theodora, Heritage. 3(2), 152 (2020)

4. J.-P.D. Addie, M. R. Glass, J. Nelles, Regional Science, 7(1), 10 (2020)

5. D. L. Bennett, Journal of Business Venturing, 34(5), 105907 (2019)

6. A. Pereira, J. Andraz, Journal of Economic Development, 38(4), 1 (2013)

7. H. Wang, W. Xiong, G. Wu, D. Zhu, Public Management Review, 20(2), 293 (2018)

8. D. B. Audretsch, D. Heger, T. Veith, Small Bus. Econ., 44(2), 219 (2015)

9. Order of the Government of the Russian Federation of March 23, 2019 No. 510-r On approval of the Methodology for the formation of the urban environment quality index

10. Analytical review of InfraONE Research «Infrastructure of Russia: index development - 2019» (2019)

11. D. Rehak, P. Senovsky, M. Hromada, T. Lovecek, International journal of critical infrastructure protection, 25, 125 (2019)

12. J. M.C.d. Silva, E. Wheeler, Perspectives in Ecology and Conservation, 15(1), 32 (2017)

13. E. V. Ufimtseva, I. V. Volchkova, M. N.D anilova, N. R. Shadeyko, Yu. V. Podoprigora, A. A. Seliverstov, Management Issues, 3(40), 81 (2016)

14. O. V. Komarova, Institute for State Support of Small Business and Problems of Its Development in Russia, 128 (2007)

15. N. Frederiksen, S. C. Gottlieb, R. Leiringer, International Journal of Project Management, 39(3), 223 (2021) 